(๑) Group of authors, 2018

UDC 616.248-07-477.75

DOI - https://doi.org/10.14300/mnnc.2018.13099

ISSN - 2073-8137

\title{
POLYMORPHIC VARIANTS OF THE TLR6 GENE IN ADULT PATIENTS WITH BRONCHIAL ASTHMA
}

\author{
Barycheva L. YU., Shushanova L. V., Yagoda A. V., Golubeva M. V., Minasyan M. M.
}

Stavropol State Medical University, Russian Federation

\section{ПОАИМОРФНЫЕ ВАРИАНТЫ ГЕНА TLR6 У ВЗРОСАЫХ ПАЦИЕНТОВ С БРОНХИААЬНОЙ АСТМОЙ}

\author{
А. Ю. Барычева, А. В. Шушанова, А. В. Ягода, М. В. Голубева, М. М. Минасян \\ Ставропольский госуАарственный меАицинский университет, \\ Российская ФеАерация
}

Immunogenetic studies were performed in 65 people with allergic bronchial asthma (BA) and 35 with non-allergic BA. This study established that the molecular genetic markers for an increased risk of allergic BA are allele TLR6 745C and TLR6 C745T. This association of polymorphic markers of the TLR6 gene is confirmed only for allergic BA. An increased risk of allergic asthma was found in carriers of the common allele TLR6 $745 \mathrm{C}$ and those with the heterozygous genotype C745T.

Keywords: bronchial asthma, Toll-like receptors, gene polymorphism

Иммуногенетические исследования выполнены у 65 человек с аллергической бронхиальной астмой, у 35 - с неаллергической бронхиальной астмой. Установлено, что носительство полиморфного маркера TLR6 745C является генетическим фактором риска развития бронхиальной астмы. Ассоциация полиморфных маркеров гена TLR6 подтверждена только для аллергической бронхиальной астмы. Выявлено увеличение риска развития аллергической БА у респондентов распространенного аллеля $T L R 6$ 745C и гетерозиготного генотипа C745T.

Ключевые слова: бронхиальная астма, рецепторы врожденного иммунитета, генный полиморфизм

For citation: Barycheva L. Yu., Shushanova L. V., Yagoda A. V., Golubeva M. V., Minasyan M. M. POLYMORPHIC VARIANTS OF THE TLR6 GENE IN ADULT PATIENTS WITH BRONCHIAL ASTHMA. Medical News of North Caucasus. 2018;13(3): 536-537. DOI - https://doi.org/10.14300/mnnc.2018.13099

Для цитирования: Барычева Л. Ю., Шушанова Л. В., Ягода А. В., Голубева М. В., Минасян М. М. ПОЛИМОРФНЫЕ ВАРИАНТЫ ГЕНА TLR6 У ВЗРОСЛЫХ ПАЦИЕНТОВ С БРОНХИАЛЬНОЙ АСТМОЙ. МедИцинскиЙ вестник Северного Кавказа. 2018;13(3):536-537. DOI - https://doi.org/10.14300/mnnc.2018.13099

$\begin{array}{ll}\text { BA } & \text { - Bronchial Asthma } \\ \text { IL } & \text { - Interleukin }\end{array}$
TLRs - Toll-Like Receptors

TSCP - Thymic Stromal Lymphopoietin
B ronchial asthma (BA) can be attributed to a typical multifactorial disease that develops due to the complex interaction of many genes, environmental factors (triggers), and geneenvironment interactions [1]. Prominent in the study of BA are the Toll-like receptors (TLRs), which are considered serious risk factors for asthma in that they control immune recognition, immune regulation, and the synthesis of inflammatory mediators; thus, they directly contribute to hyperreactivity of the bronchial tree and airway remodeling $[1,2]$.

It is known that stimulation of TLRs initiates the secretion of pro-inflammatory cytokines, as well as proallergic mediators, such as thymic stromal lymphopoietin (TSCP) and interleukins IL-25 and IL-33; this enhances the Th2mediated response $[1,2,3]$. It is believed that TLRs affect the polarization and development of $\mathrm{T}$ lymphocytes, which are key events in the induction and chronicization of asthma and atopy [3].
Aim of the investigation was to determine the clinical and pathogenetic significance of polymorphic markers of the receptor of congenital immunity, TLR6, in the development of allergic and non-allergic phenotypes of BA.

Material and Methods. Immunogenetic studies were performed in 100 patients with bronchial asthma, who were under surveillance in the city polyclinic. Allergic asthma was diagnosed in 65 patients; non-allergic asthma was diagnosed in 35. Patients included in the study were aged between 20 and 75 years; the median age in the allergic asthma group was $34[23.5,45]$, while that in the nonallergic asthma group was 61 [47, 66]. The control group included 50 practically healthy people of Russian nationality in the Southern region of the Russian Federation aged between 18 and 60 years; the median age was 36 [24, 43.5].

Typing of SNPs in TLR6 was performed by using restriction fragment length polymorphism with amplification of the site of interest and subsequent treatment with restriction endonuclease. Litech diagnostic kits (SNP 
Express, LLC) were used to detect polymorphisms in the human genome by polymerase chain reaction.

Amplification was performed by using a Terzik multichannel thermocycler (DNA Technology LLC, Russia). Separation of the amplification products was performed in a $3 \%$ agarose gel by horizontal electrophoresis with equipment from BioRad Laboratories (USA).

For statistical analysis of the data, the following programs were used: Attestat 10.5.1., Statistica SPSS, and Calculator for calculating statistics (http://www.gen-expert. $\mathrm{ru})$. The reliability of differences in the frequencies of allelic variants and genotypes was evaluated by using the Pearson $\chi^{2}$ test, with multiple comparisons performed by using the $\chi^{2}$ criterion with the Yates correction. The risk of events was assessed as the odds ratio (OR), with a $95 \%$ confidence interval $(\mathrm{Cl})$.

Results and Discussion. In this study of the gene polymorphism of TLR6 C745T (Ser249Pro), the common allele, $745 \mathrm{C}$ ( $46 \%$ and $30 \%, p<0.05$ ), was detected more frequently in patients with $\mathrm{BA}$ than in healthy controls. Less frequently, the minor $745 \mathrm{~T}$ allele $(54 \%$ and $70 \%, p<0.05$ ) was detected in BA patients. The relative risk of developing disease among patients with the dominant allele was 1.99 (95 \% Cl: 1.19-3.31).

In the analysis of genotypes, there was a significant reduction in the homozygous genotype with respect to the minor allele, T745T (27\% and $52 \%, \mathrm{p}<0.05)$, compared with healthy controls; the probability of development of asthma was substantially reduced in such patients in the codominant model $(\mathrm{OR}=0.34,95 \% \mathrm{Cl}$ : $0.17-0.69)$. The low risk of BA in homozygous patients with the rare T745T allele was confirmed in the recurrent model $(\mathrm{OR}=0.34, \mathrm{Cl}$ : $0.19-0.69), p<0.001$.

In the analysis of clinical BA phenotypes, the association of polymorphic markers of the TLR6 gene was established only for patients with allergic asthma. Carriage of the dominant allele was exhibited more often in patients with allergic asthma than in patients with non-allergic asthma $(56.2 \%$ and $28.6 \%, p<0.001)$, or in healthy controls $(56.2 \%$ and $30 \%, p<0.001)$ with allele $745 \mathrm{C}$, more rarely a minor one, 745T. The probability of developing allergic asthma in the holders of the major allele was elevated by almost 3-fold; the relative risk of developing the disease was 2.99 (95\% Cl: 1.77-5.18).

Notably, in patients with allergic asthma, the homozygous genotype was more prevalent than in patients with nonallergic asthma $(26.1 \%$ and $5.7 \%, p<0.05)$, consistent with the commonality of the $\mathrm{C} 745 \mathrm{C}$ allele in the population. In non-allergic asthma, conversely, the homozygous variant was dominant for the rare T745T allele (51.4\% and $15.4 \%$, $\mathrm{p}<0.001)$.

Carriers of the heterozygous genotype C745T have an increased risk of developing allergic asthma $(\mathrm{OR}=2.50 ; 95 \%$ $\mathrm{Cl}$ : 1.17-5.35); in carriers of the homozygous genotype T745T, there was a reduction in the probability of verification of allergic asthma, OR=0.16 (95\% Cl: 0.07-0.40).

The presence of a rare $745 \mathrm{~T}$ allele reduced the risk of developing allergic asthma for T745T homozygous patients, which was confirmed in a recessive model, OR=0.17 (95\% $\mathrm{Cl}: 0.07-0.40)$. These results are consistent with the data of foreign researchers that showed polymorphic TLR6 markers are significantly associated with asthma phenotypes $[4,5]$.

Conclusions. Carriage of the TLR6 $745 \mathrm{C}$ polymorphic marker may constitute a genetic risk factor for the development of BA, whereas the presence of a homozygous genotype in the minor T745T allele reduces the risk of developing asthma and exhibits protective properties.

This association of polymorphic markers of the TLR6 gene is confirmed only for allergic BA. An increased risk of allergic asthma was found in carriers of the common allele TLR6 745C and those with the heterozygous genotype C745T; in contrast, a decreased risk was found in carriers of the rare 745T allele and those who were homozygous for the rare allele of the T745T genotype.

Disclosures:

The authors declare no conflict of interest.

Acknowledgements. We thank Ryan Chastain-Gross, Ph.D., from Edanz Group (www.edanzediting.com/ac) for editing a draft of this manuscript.

References

1. Alexis N. E. Biomarker sampling of the airways in asthma. Curr. Opin. Pulm. Med. 2014:20(1):46-52 https://doi.org/10.1097/MCP.0000000000000010

2. Maisonneuve C., Bertholet S., Philpott D. J., De Gregorio E. Unleashing the potential of NOD- and Tolllike agonists as vaccine adjuvants. Proc. Sci. 2014;111(34):12294-12299. https://doi.org/10.1073/pnas.1400478111

3. Sathish V., Thompson M. A., Sinha S., Sieck G. C. Prakash Y.'S. [et al.] Inflammation, caveolae and CD38mediated calcium regulation in human airway smooth muscle. Biochim. Biophys. Acta. 2014;1843(2):346351. https://doi.org/10.1016/j.bbamcr.2013.11.011

4. Koponen P., Vuononvirta J., Nuolivirta K., Helminen M. $\mathrm{He} \mathrm{Q}$. [et al.] The association of genetic variants in tolllike receptor 2 subfamily with allergy and asthma after hospitalization for bronchiolitis in infancy. Pediatric Infect. Dis. J. 2014;33(5):463-466. https://doi.org/10.1097/INF.0000000000000253

5. Kormann M. S., Depner M., Hartl D., Klopp N., Illig T. [et al.] Toll-like receptor heterodimer variants protect from childhood asthma. J. Allergy Clin. Immunol. 2008;122:8692. https://doi.org/10.1016/j.jaci.2008.04.039

\footnotetext{
About authors:

Barycheva Lyudmila Yur'evna, MD, DMSc, Professor, Head of the Department of Immunology with the course of APE; tel.: +79187405484; e-mail: for_ludmila@inbox.ru

Shushanova Liliya Vladimirovna, MD, Assistant of immunology Department of Immunology with course of APE; tel.: +79197355961; e-mail: schuschanova.lili@yandex.ru

Yagoda Alexander Valentinovich, MD, DMSc, Professor, Head of the Department of Hospital Therapy; tel.: +79064907330; e-mail: alexander.yagoda@gmail.com

Golubeva Marina Viktorovna, MD, DMSc, Professor, Head of the Department of Children's Infectious Diseases;

tel: +79187468795; e-mail: mmvg@rambler.ru

Minasyan Milana Mihajlovna, MD, Assistant of the Department of Immunology with course of APE;

tel.: +79280072808; e-mail: m.milana84@mail.ru
} 